\title{
Temporal variations of body mass and plumage in Arenaria interpres (Aves: Scolopacidae) along the Brazilian coast
}

\author{
Roberta C. Rodrigues 1, 3; Severino M. de Azevedo-Júnior 1; \\ Maria E. L. de Larrazábal ${ }^{1} \&$ Helder F. P. de Araujo ${ }^{2}$
}

\author{
1 Programa de Pós Graduação em Biologia Animal, Universidade Federal de Pernambuco. Avenida Professor Moraes Rego \\ 1235, Cidade Universitária, 50670-420 Recife, Pernambuco, Brasil. \\ 2 Programa de Pós Graduação em Ciências Biológicas, Universidade Federal da Paraíba. Campus Universitário, \\ 58059-900 João Pessoa, Paraíba, Brasil. \\ 3 Corresponding author. E-mail: robertacrodrigues@gmail.com
}

\begin{abstract}
Every year, Brazil receives large flocks of nearly 40 migratory shorebirds species. The accumulation of body fat and nutrients during the summer is necessary for the long return flights of these birds and is fundamental for feather moulting and the change of their plumage. We present here an examination of the relationship between body mass and plumage change in Arenaria interpres (Linnaeus, 1758), one of those birds, over time during its wintering period on the Brazilian coast. We analyzed information collected at five traditional stopover sites along the Brazilian coast, between 1997 and 2007. During the month of September, individuals with intermediate or breeding plumage had smaller body masses as compared to other months. From October to December, adult individuals were only observed with eclipse plumage and had average body masses of approximately $100 \mathrm{~g}$. In March, individuals with intermediate, eclipse and breeding plumages were recorded, but their average body mass remained at approximately $100 \mathrm{~g}$. In April and May the numbers of individuals with breeding or intermediate plumage increased, and they showed significant increases in body mass at a rate of approximately 1.5 and $2.3 \mathrm{~g}$ per day, in the north-northeastern and south coast, respectively, leading to an average mass of 124 and $143 \mathrm{~g}$ in these months. That is suggested to be the departure mass of $A$. interpres in the Brazilian north-northeastern and south coast, respectively, when starting the migration to the breeding sites.
\end{abstract}

KEY WORDS. Migration; moult body; turnstone; shorebird; wintering sites.

Many migratory bird species that reproduce in the Artic region migrate towards the southern hemisphere as the boreal winter approaches (BERTHOLD 1993), and these long migrations are related to the reproductive cycle of the Nearctic migratory Charadriiformes. The adult individuals of these species leave their breeding regions toward wintering areas in North and South America, where they will moult and then acquire new plumage (HARRINGTON \& MORRISON 1979).

Every year Brazil receives large flocks of nearly 40 migratory shorebirds species (AzEvEDo-JúNIOR 1998). ANTAS (1983) described four main migratory routes in the country. The Atlantic Route describes a pathway from Amapá to Rio Grande do Sul, with a number of wintering sites along the coast. These wintering sites are important areas for maintaining these populations and conserving many distinctive species (Telino-JúNIOR et al. 2003).

The accumulation of body fat and nutrients during the summer is necessary for the long return flights of these birds and is fundamental for feather moulting and the change of their plumage (Gils \& Wiersma 1996, Battley 1999)0. As such, body mass is an essential factor in our understanding of the migration patterns. Each pattern of body-mass gain in these birds represents a different survival strategy - short flights with many stopping points for feeding, for example, or long-distance flights with few resting or feeding stops along the way (ZWARTs et al. 1990).

Arenaria interpres (Linnaeus, 1758) (Aves, Scolopacidae) is a long-distance migratory bird with circumpolar distribution. These birds reproduce in the Arctic region and immature individuals spend the boreal summers in those same sites. Five populations of this species have been identified migrating along different routes. These different groups reproduce in northeastern Alaska and the Canadian Arctic and then move along the Pacific and Atlantic coasts toward Central and South America, concentrating large numbers of wintering birds along the eastern coast of both North America and South America (GiLs \& Wiersma 1996).

In Europe, Africa and Australia relations between moult, mass variation and pre-migratory and wintering period in some shorebirds, including $A$. interpres have been described (e.g. Sum- 
MERs et al. 1989, ENs et al. 1990, ZwARTs et al. 1990, HARRINGTON et al. 1991, Gils \& Wiersma 1996, Helseth et al. 2005). We present here an assessment of the relationship between body mass and plumage change in $A$. interpres over time during its wintering period on the Brazilian coast.

\section{MATERIAL AND METHODS}

The information used in our analyses originated from the data bank maintained by the Centro Nacional de Pesquisa para Conservação das Aves Silvestres (Cemave/ICMBio), as well as from field research undertaken by the authors from 1997 to 2007. The traditional stopover sites (Fig. 1) along the Brazilian coast were: 1) Parazinho Island, Bailique Archipelago, state of Amapá $\left(0^{\circ} 53^{\prime} \mathrm{N}, 49^{\circ} 59^{\prime} \mathrm{W}\right)$ : was established as a State Biological Reserve since 1989 due to its importance as a stopover site for migratory birds and as an egg-laying locality for the Amazonian turtle Podocnemis expansa (Schweigger, 1912) (Testudines: Pelomedusidae). 2) Reentrâncias Maranhenses Environmental Protection Area, state of Maranhão ( $\left.1^{\circ} 22^{\prime} \mathrm{S}, 44^{\circ} 56^{\prime} \mathrm{W}\right)$ : designated by the Western Hemispheric Shorebird Reserve Network in 1991 as an internationally important site receiving large populations of migratory birds, it was also included in the Ramsar Convention. 3) Diamante Branco Saline, Galinhos, state of Rio Grande do Norte $\left(05^{\circ} 05^{\prime} \mathrm{S}, 36^{\circ} 16^{\prime} \mathrm{W}\right)$ : this site is considered to be one of the most important salt flats in Brazil. In addition to the 2,500 ha used for salt extraction, the area also has sandy beaches, estuaries, and mangrove swamps. 4) Coroa do Avião, Igarassu, state of Pernambuco $\left(7^{\circ} 40^{\prime} \mathrm{S}, 34^{\circ} 50^{\prime} \mathrm{W}\right)$ : a small island that was formed by sand deposition in the 1980's at the mouth of the Canal de Santa Cruz river on the northern coast of the state of Pernambuco, approximately $50 \mathrm{~km}$ north of the state capital at Recife. 5) Lagoa do Peixe National Park, Tavares, state of Rio Grande do Sul $\left(31^{\circ} 10^{\prime} \mathrm{S}, 51^{\circ} 0^{\prime} \mathrm{W}\right)$. This National Park covers an area of 34,000 ha. The area was included in the Hemispheric Shorebird Reserve Network, and was recently established as a Biosphere Reserve.

Birds were considered as adults if they displayed the characteristic eclipse (no-breeding), intermediate, or breeding plumage (Hayman et al. 1988). The designation of moulting refers to the body feathers (GinN \& Melville 1995) and the body mass was obtained using a dynamometer.

Due to geographical distances, the data of sites of the north and northeastern were analyzed separately of the data obtained in Brazil south. Body mass and plumage types (eclipse, intermediate, and breeding) of adult individuals were compared using the analysis of variance (ANOVA). In order to establish the existence of temporal variations in body mass and plumage acquisition, the body masses and the plumage percentages were graphed on a daily basis from September to May, which corresponds to the wintering period for $A$. interpres along the Brazilian coast. A regression equation was also derived in order to estimate daily mass gain during the departure period (April and May - the period of greatest mass gain; see results. Analy-

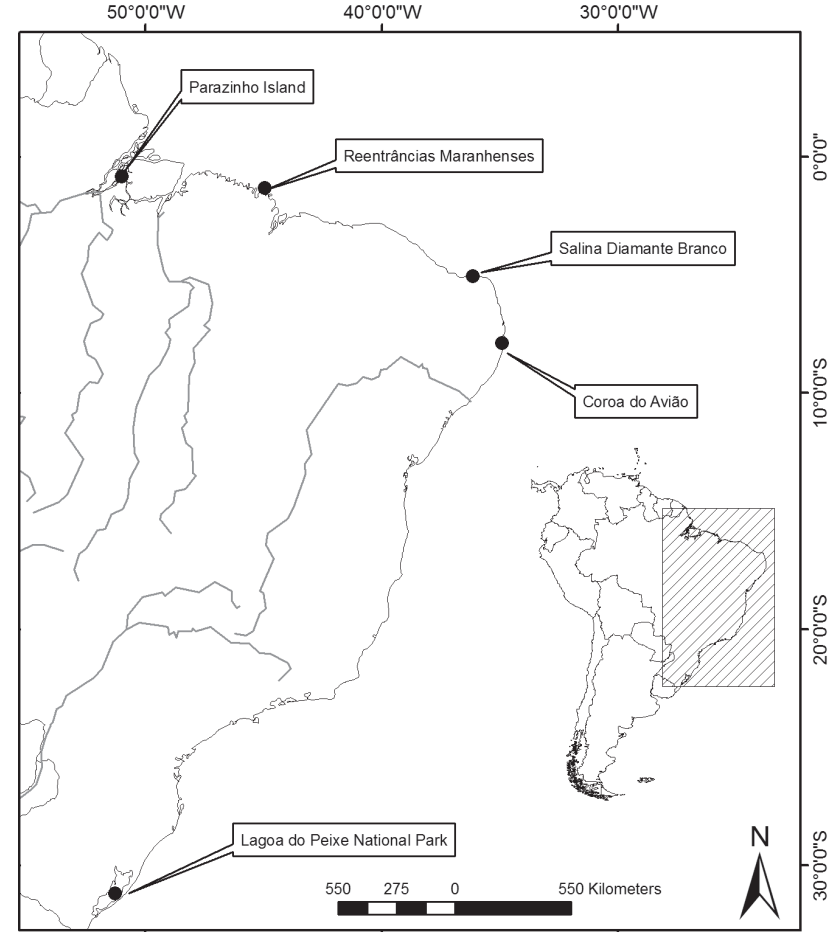

Figure 1. Traditional stopover sites along the Brazilian coast where the data-field were collected.

sis of variance was also used to compare body mass among individuals with different types of plumage and those were or were not in the process of body moult. Statistical analyses were performed using Statistica 7.0 (StatSoft, Inc.) software package. Significance level was set at $\mathrm{p}<0.05$.

\section{RESULTS}

Of 190 examined individuals of the Brazilian north-northeastern coast, 50\% demonstrated eclipse plumage and had an average body mass of $97.77 \mathrm{~g}$ (sd:8.27; range:118-76); 13\% had intermediate plumage and an average body mass of $113.92 \mathrm{~g}$ (sd: 24.31, range: $150-80$ ); while $37 \%$ had breeding plumage and an average body mass of $113.34 \mathrm{~g}$ (sd: 16.58, range:15474). Of the Lagoa do Peixe, south coast, 28 individuals were examined, $25 \%$ of those had eclipse plumage and average mass of $98.57 \mathrm{~g}$ (sd: 11.29, range: 118-80); 36\% had intermediate plumage and average mass of $117.7 \mathrm{~g}$ (sd: 32.03, range: 18085); and 39\% demonstrated breeding plumage and had an average body mass of $128.9 \mathrm{~g}$ (sd: 31.45 , range: 184-95). The masses varied significantly with the plumages, in the northnortheastern coast, where individuals with intermediate and breeding plumages demonstrated higher values than individuals with eclipse plumage (Fig. 2). Although significant variation has not been observed in the south coast, the masses of the individuals with intermediate and breeding plumages were 

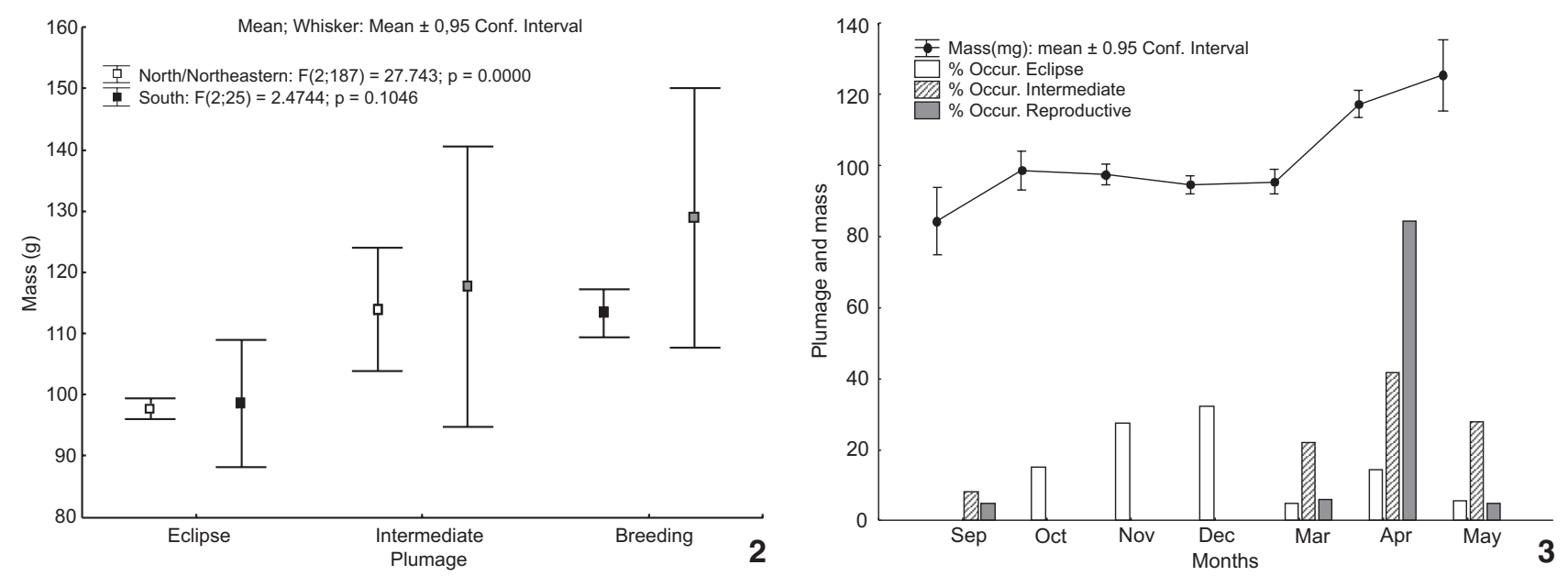

Figures 2-3. (2) Comparison among the body masses of individuals of $A$. interpres with different plumages along the Brazilian coast. (3) Temporal variation of mass and plumage in $A$. interpres during their over-winter period on the Brazilian coast.

larger than eclipse (Fig. 2). Perhaps the confidence intervals of Lagoa do Pexe data were big due to the small $n$ of samples, when compared to northnortheastern coast.

During the month of September, individuals with intermediate or breeding plumage had lower body masses as compared to other months (Fig. 3). From October to December, adult individuals were only observed with eclipse plumage and had average body masses of approximately 100 g. In March, individuals with intermediate, eclipse and breeding plumages were recorded, but their average body mass remained at approximately $100 \mathrm{~g}$. In April and May the numbers of individuals with breeding or intermediate plumage increased, and they had significant increases in body mass.

A regression equation was derived for the pre-migratory mass increase period based on the mean mass of individuals in April and May. In the north-northeastern coast, the birds'body mass increased $1.5 \mathrm{~g} / \mathrm{day}$, on average (mass $=90.2273+1.1498^{*}$ day), which corresponds to an average daily percentage weight gain of $1.86 \%$ when starting from the body mass observed in the last days of March; while in the south coast, the increase was of $2.3 \mathrm{~g} /$ day, on average (mass $=77.6634+2.3329^{*}$ day), which corresponds to an average daily percentage weight gain of $2.29 \%$.

The body masses of individuals varied in agreement with the occurrence of moult in the two areas, north-northeastern $(\mathrm{F}=9.8322, \mathrm{p}<0.0001)$ and south coast $(\mathrm{F}=5.1693, \mathrm{p}=0.0502)$. In both cases, the masses of the non-moulting birds with intermediate and breeding plumage were larger than the body masses of individuals with moult or eclipse plumage (Fig. 4).

The average body mass of birds with eclipse plumage between December and March, in the north-northeastern coast, was $102 \mathrm{~g}$; an average mass of $111 \mathrm{~g}$ was recorded during the months of April and May for birds with intermediate or breeding plumage and that were moulting their body feathers; an average body mass of $124 \mathrm{~g}$ was recorded for individuals with intermediate or breeding plumage that had completed (or suspended) their body feathers moult between April and May. In the south coast, those mass values were 101, 110 and $143 \mathrm{~g}$, respectively.

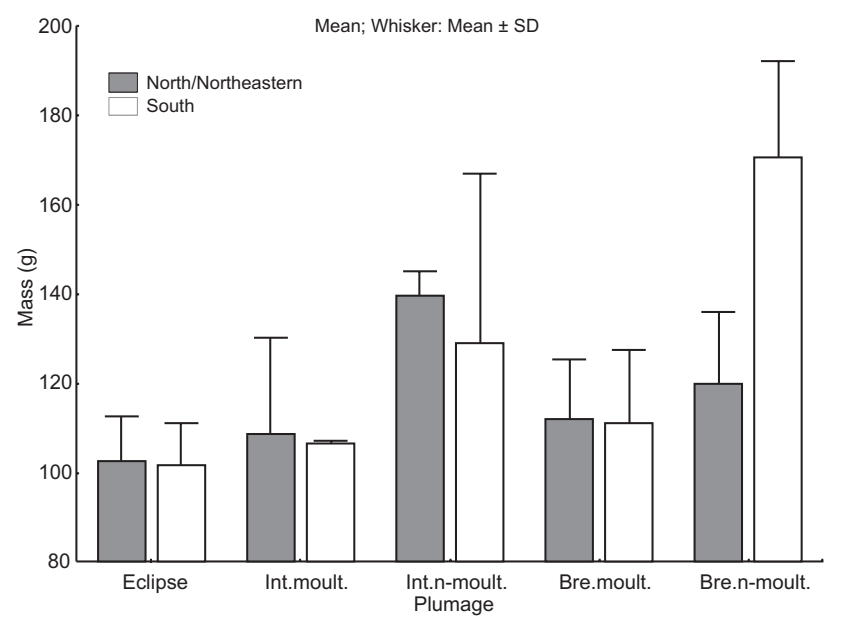

Figure 4. Correlation between the body masses of individuals of $A$. interpres over time in April and May.

\section{DISCUSSION}

The winter period of Charadriiformes along the Brazilian coast extends from August to May (Gils \& Wiersma 1996, RodRIGUEs 2000). The arrival of $A$. interpres with breeding or intermediate plumage during September is associated with birds with residual plumage from their reproductive period. Between 
October and February, this species displays eclipse plumage. In March, individuals with intermediate or breeding plumage begin to appear, increasing in frequency in April and May (the months in which this species begins its migration towards the northern hemisphere) (AzEvEdo-Júnior et al. 2001). During May and June, large flocks of these birds concentrate on the eastern coast of North America (CLARK \& Niles 1993).

The populations of $A$. interpres that wintering in Scotland, Sweden, Australia, South Africa, and Mauritania return to the Northern Hemisphere during April and May (Summers et al. 1989, Gils \& Wiersma 1996, Ens et al. 1990, ZwarTs et al. 1990, HeLSETh et al. 2005), following the beginning of the substitution of the eclipse plumage by intermediate or breeding plumage in March in Mauritania (ENs et al. 1990, ZwARTs et al. 1990). These patterns suggest that the biological cycles regulating plumage changes and migration patterns in this species are temporally equivalent, independent of their migratory routes.

Body mass is directly involved in the process of migration, and various authors have examined this relationship in other species of Charadriiformes (e.g., Summers et al. 1989, ENs et al. 1990, Zwarts et al. 1990, Harrington et al. 1991, BatTley 1999, Azevedo-Junior et al. 2002, Balachandran et al. 2000, Fedrizzi et al. 2004, Helseth et al. 2005, Meissner \& Kamont 2005). Zwarts et al. (1990) demonstrated that a sudden and continuous loss of body mass occurs in captured birds, which must be taken into account in studies that examine and compare body mass. In the case of the present work, however, we were not greatly concerned with this type of weight loss as the birds were weighed no more than two hours after capture - while the highest rates of weight loss begin three hours after capture (ZwARTs et al. 1990). Generally, a large interval between capture and processing only occurs when captures are made using cannon nets - in which the number of captured individuals is very high in comparison to the mist-nets used in the present work.

The increase in body mass and the substitution of eclipse plumage by intermediate or breeding plumage occurs simultaneously in $A$. interpres along the Brazilian coast. This synchrony between mass gain and plumage acquisition has also been confirmed in various other species of Charadriiformes during their pre-migratory period, and was previously described for $A$. interpres in Mauritania (ENs et al. 1990, ZwARTs et al. 1990).

Since the work of STRESEMAnN \& STRESEMAnN (1966), it has been widely accepted that migration and changes in wing feathers are mutually exclusive processes. However, this association is not as clear for changes in body feathers (ZwARTs et al. 1990). The data presented here demonstrates that the heaviest individuals are not moulting body feathers, whereas those birds undergoing body-feather moult, even pre-nuptial plumage in the months of April and May, have significantly less body mass (a mass equivalent to that seen in individuals with eclipse plumage or to that seen among the general population during the month of March). This data supports the assertion that migration and moult are mutually exclusive processes, even body moult. ZwARTs et al. (1990) demonstrated that birds that will migrate over long distances but have not completed their prenuptial moult (although otherwise ready to initiate migration) can suspend that moult and then continue it in localities nearer to reproduction sites.

As moult and migration are not simultaneous processes in A. interpres wintering along the Brazilian coast, we suggest that the average body mass at the start of migration in this species is $124 \mathrm{~g}$ in the north-northeastern coast and $143 \mathrm{~g}$ in the south coast, corresponding to the average body mass of those individuals with intermediate or breeding plumage and not undergoing moult. This mass represents an increase of almost 30 and $45 \%$ in relation to the average mass observed until the month of March, respectively (that is, before the start of body mass accumulation). Ens et al. (1990) reported that the departure body mass of $135 \mathrm{~g}$ for $A$. interpres in Mauritania is equivalent to an increase of 35\%, which is very close to the 34\% increase noted by ZWARTs et al. (1990). SuMmERs et al. (1989) found increases of approximately 28 and $44 \%$ in body mass in the months of April and May respectively in South Africa, although the absolute average departure masses for these birds were 147 and $164 \mathrm{~g}$ respectively. These authors also noted a mass increase of approximately $28 \%$ in $A$. interpres in May alone in Scotland, with the birds there reaching an average weight of $132 \mathrm{~g}$. These comparisons suggest that the increase in body mass in $A$. interpres is related to migration distances. In Europe, where breeding sites are closer to the wintering sites, mass gain is reduced and concentrated into a single month (May); along the north-northeastern coast of Brazil and Mauritania (at relatively equivalent latitudes) body mass accumulation was between 30 and 35\% during two months (April and May); in these same two months in Brazilian south coast and South Africa, the increase came to 45 and $44 \%$, respectively. The largest average departure masses was also observed in Brazilian south coast and South Africa, between 143 and $155 \mathrm{~g}$, while the average departure masses varied between 124 and $135 \mathrm{~g}$ in the other regions.

ZwARTs et al. (1990) reported that the departure mass could not be reliably estimated from the average mass of birds with intermediate or breeding plumage. The authors suggest an estimate using the largest masses of half of the frequency of those birds. In the present work, this estimated value would be 129 and $150 \mathrm{~g}$, in the north-northeastern and south coast, respectively. However, as ZwarTs et al. (1990) observed, the birds are ready to leave when they have completed or suspended their pre-nuptial moult. As such, we assume that the departure mass is the body mass of those individuals with intermediate or breeding plumage that are not moulting, as was discussed earlier. The period in which the individuals have body masses greater than or equivalent to that departure mass occurs in the last two weeks of April and in the first weeks of May, similar to the situation reported by Ens et al. (1990) in Mauritânia. This period is considered the departure time for $A$. interpres from the Brazilian coast in their movement towards the Northern Hemisphere. 


\section{ACKNOWLEDGMENTS}

We thank Universidade Federal de Pernambuco, Universidade Federal Rural de Pernambuco and Centro de Pesquisas para Conservação das Aves Silvestres (CEMAVE) for supporting this research and for available data-field. R.C. Rodrigues receive a master's scholarship of the Conselho Nacional de Desenvolvimento Científico e Tecnológico (CNPq) and H.F.P. Araujo receive a doctor's scholarship of the Coordenação de Aperfeiçoamento de Pessoal de Nível Superior (CAPES). We also thanked the reviewers for the contributions to the manuscript.

\section{LITERATURE CITED}

ANTAS, P.T.Z. 1983. Migration of neartic shorebirds (Charadriidae and Scolopacidae) in Brazil - flyways and their different seasonal use. Wader Study Group Bulletin 39: 52-56.

Azevedo Júnior, S.M. 1998. As aves do Canal de Santa Cruz, Pernambuco Brasil. Caderno Ômega da Universidade Rural de Pernambuco, Série Ciências Aquáticas 5: 35-50.

Azevedo JúnIor, S.M.; M.M. Dias \& M.E.L. De LaRRAZÁbal. 2001. Plumagens e mudas de Charadriiformes (Aves) no litoral de Pernambuco, Brasil. Revista Brasileira de Zoologia 18 (3): 657-672.

Azevedo Júnior, S.M.; M.M. Dias Filho; M.E.L. de Larrazábal \& C.J.G. Fernandes. 2002. Capacidade de vôo de quatro espécies de Charadriiformes (Aves) capturadas em Pernambuco, Brasil. Revista Brasileira de Zoologia 19 (Supl. 1): 183-189.

Balachandran, S.; S.A. Hussain \& L.G. Underhill. 2000. Primary moult, biometrics, mass and age composition of Grey Plovers Pluvialis squaratola in southeastern India. Bird Study 47: 82-90.

Battley, P.F. 1999. Seasonal mass of Lesser Knots (Calidris canutus) in New Zealand. Notornis 46: 143-153.

Berthold, P. 1993. Bird Migration. A general survey. Oxford, Oxford University Press, 420p.

Clark, K.E. \& L.J. Niles. 1993. Abundance and distribution of migrant shorebirds in Delaware Bay. Condor 95: 694-705.

Ens, B.J.; P. Duiven, C.J. Smit; T.M. Van Spanje. 1990. Spring migration of turnstones from the Banc D'Arguin in Mauritania. Ardea 78: 301-314.

Fedrizzi, C.E.; S.M. de Azevedo-Júnior; M.E.L. de LarrazÁbal. 2004. Body mass and acquisition of breeding plumage of wintering Calidris pusilla (Linnaeus) (Aves, Scolopacidae) in the coast of Pernambuco, north-eastern Brazil. Revista Brasileira de Zoologia 21 (2): 249-252.

Gils, J. \& E.P. Wiersma. 1996. Family Scolopacidae, species account, p. 489-533. In: J. Hoyo; A. Elliot \& J. Sargatal (Eds). Handbook of the birds of the world. Barcelona, Lynx Editions, 821p.

Ginn, H.B. \& D.S. Melville. 1995. Moult in birds. Tring, Hertfordshire, British Trust for Ornithology, 112p.

Harrington, B.A. \& R.I.G. Morrison. 1979. Semipalmated Sandpiper (Calidris pusilla). Wader Study Group Bulletin 33: 37-38.

Harrington, B.A.; F.J. Leeuwenberg; S. Lara-Resende; R. McNeil; B.T. Thomas; J.S. Grear \& E.F. Martinez. 1991. Migration and mass change of White-Rumped sandpipers in North and South America. Wilson Bulletin 103 (4): 621-636.

Hayman, P.; J. Marchant \& T. Prater. 1988. Shorebirds, an identification guide to the waders of the world. Boston, Hougton Mifflin Company, 412p.

Helseth, A.; M. Stervander \& J. Waldenström. 2005. Migration patterns, population trends and morphometrics of Ruddy Turnstones Arenaria interpres passing through Ottenby in south-eastern Sweden. Ornis Svecica 15: 63-72.

Meissner, W. \& P. Kamont. 2005. Seasonal changes in body size and mass of red knots Calidris canutus during autumn migration through southern Baltic. Ornis Svecica 15: 97-104.

Rodrigues, A.A.F. 2000. Seazonal abundance of neartic shorebirds in the gulf of Maranhão, Brazil. Journal of Field Ornithology 71 (4): 665-675.

Stresemann, E. \& V. Stresemann. 1966. Die Mausen der Vögel. Journal für Ornithology 107 (special number.): 1-445.

Summers, R.W.; L.G. Underhill; C.F. Clinning \& M. Nicoll. 1989. Populations, migrations, biometrics and moult of the turnstone Arenaria i. interpres on the east atlantic costline, with special reference to the siberian population. Ardea 77 (2): 145-168.

Telino-Júnior, W.R.; S.M. Azevedo Júnior \& R.M. De Lyra-Neves. 2003. Censo de aves migratórias (Charadriidae, Scolopacidae e Laridae) na Coroa do Avião, Igarassu, Pernambuco, Brasil. Revista Brasileira de Zoologia 20 (3): 451-456.

Zwarts, L.; B.J. Ens; M. Kersten \& T. Piersma. 1990. Moult, mass and flight range of waders ready to take off long-distance migrations. Ardea 78: 339-364.

Submitted: 18.VI.2008; Accepted: 04.IX.2009.

Editorial responsibility: Luciano M. Verdade 